\title{
Show-girl: The Staging of Lotti Wilmot
}

\author{
BRONWYN DALLEY
}

\section{Prologue: A Sunday Evening in Christchurch, 1881}

Madame Lotti Wilmot knew how to give a gentleman a good thrashing. She was quick to reach for a supple cane when crossed, so it may not have been a surprise to anyone when an argument outside the Papanui Town Hall turned physical. It was November 1881 and "the celebrated lecturess and advanced progressionist" was in Christchurch, giving Sunday evening talks at the Papanui Town Hall. ${ }^{1}$ As an avowed freethinker, Lotti loved to goad the local religious establishment by speaking on a Sunday evening and charging admission to her lectures. $^{2}$

If her previous visit to Canterbury was anything to go by, Lotti's lectures were sure to attract interest. With titles such as "Forbidden Fruit," "Courtship and Marriage," "The Social Evil" or "His Majesty the Devil," the audience knew they would hear something provocative or startling. More titillating content could be expected in Lotti's exposé of the seamier side of city life in "Christchurch by Day and Christchurch by Night." Whatever the topic, Lotti would use it as a platform for illustrating the hypocrisies of clergy, Christians in general, local worthies and upstanding citizens. It was no wonder her talks met with applause and umbrage in equal measure.

But at the Papanui Town Hall on 6 November, it was not Lotti's talk on "The Devil and his Angels" that created the excitement; it was her performance outside the venue. Over 30 people milled about outside the hall, hoping the lecture could start an hour early. Many had come out from the town centre by tram, and if the lecture did not start soon, they would miss the last ride home. Eager to keep her audience happy — and on hand - Lotti set about trying to get into the locked building. Whistling for the key outside the home of the town hall secretary had no effect, and the audience could not oblige her request for a crowbar to force the hall door. When the town hall secretary finally arrived on the scene 10 minutes before the scheduled start, Lotti's blood was up.

Secretary George William Coutts Moon- "smaller than his name would imply," one local newspaper quipped - was a man who held fast to the terms of a contract. He refused to budge until the agreed time. "Puny little wretch," Lotti was heard to say, and much more besides: "little thief," "low swindler" and - a good freethinking insult—"servant of the Psalm singers." Lotti was a tall woman, and took some pleasure in towering over her opponent; one witness testified he heard Lotti say that if Moon were "as big as some men," she would have killed him, but since he was just "a little man" she would let him off mercifully. Whatever her invective, all agreed that she thrashed Moon with a knobbed supplejack, upwards of 30 times according to a bystander. It was a total eclipse of the Moon, one wit chortled.

Masculine pride rather than flesh took the greater beating, and the drama moved to the courtroom the following week, where Lotti faced charges of using threatening language and assault. As was her custom, Lotti represented herself in court, taking a starring role in proceedings that periodically spilled into high farce as her cross-examination of Moon and witnesses veered off topic. She outlined conspiracies designed to damage her reputation and career. Lotti denied the threatening language, but admitted the assault with the stick she habitually carried. Although "only a woman," she occasionally found "necessity for taking her own part"; just the previous year, she claimed, someone had threatened her life.

Magistrate George Mellish, increasingly impatient with the theatrics, went to the heart of the matter. He thought the entire affair looked "very much like endeavouring to get a sensational advert cheaply." The fine of 1 s for the abusive language and £25 for the assault, plus costs, was, Lotti maintained, cheap at half the price; she got much more than $£ 20$ worth 
of satisfaction in taking to Mr Moon. Not that she had any intention of paying the fine, as it transpired. Within days she turned the tables and took the Papanui Town Hall Company to court, claiming $£ 170$ for breach of contract, and special damages to her reputation.

Cantabrians had no need to wait for that court case if they wanted the next instalment in the Lotti Wilmot show. They could attend the event which raffled Lotti's knobbly supplejack, or join the choir she formed so her "New Progressive Lyceum" in Madras St could be on the same footing as churches and hold events in central Christchurch on a Sunday.

Events similar to those in Christchurch in November 1881 occurred several times during Lotti's tours in Australia and New Zealand from the mid 1870s. The contretemps formed part of her "offstage" routine, played out in courts, newspapers, pamphlets, carefully choreographed publicity stunts and in the narratives she wrote about her life. Such events complemented Lotti's formal stage appearances in Australasia, and earlier in her native England: actress, burlesque performer, theatre manager, lecturer, medium. Audiences paid to see her in the theatre or lecture hall, but there was little else to distinguish on- and offstage performances. On the street or on the stage, Lotti cut a distinctive figure in attire and demeanour; the pet dogs that accompanied her most places completed the look.

In what follows, I examine this process of performance, particularly during Lotti's visit to Australia and New Zealand in the 1870s and 1880s, although I also discuss her earlier career in England. Lotti trod the circuit of nineteenth-century show people who travelled the English-speaking world, entertaining audiences eager for novelty and diversion. Celebrity in the nineteenth century, as now, was fleeting, and few New Zealand scholars have examined how individuals negotiated their way in this world, or in the area of popular culture more generally. $^{3}$

For a decade from the mid-1870s, Lotti Wilmot's name was well known on the Australasian entertainment circuit and in the gossip pages of the press; today, she is largely forgotten. Yet Lotti helped make the textured milieu of nineteenth-century popular cultureentertainment and leisure for the ordinary man and woman. It was a world where theatre and spectacle, religious belief and unbelief, social reform and the latest fads combined. Historians such as James Belich and Caroline Daley have made strong cases for scholars to acknowledge the boisterous nature of New Zealand society over this period, and to explore the heady excitement of city life. ${ }^{4}$ Lotti Wilmot's performances encapsulated that sense of excitement; the world of social reform, spiritualism and popular lectures could be anything but dour.

Lotti Wilmot's story goes beyond the sphere of nineteenth-century theatre and the popular entertainment circuit to highlight women's experiences by exploring how one individual "performed" gender. Repeatedly, Lotti took on different personae to suit - and to influence - the circumstances in which she found herself. Her creation and performance of these personae was an active process, sometimes done in response to opportunities at hand, sometimes as part of the relationship with her diverse audiences; this was a woman who "staged" her life. Lotti's experiences illustrate the complex juggling of parts undertaken by women in this period, especially those who lived on the edge of respectability, as a career in the theatre or on stage certainly was. Examining the staging of Lotti Wilmot enables us to view the elaborate ways in which individuals composed their own identities that challenged and reinforced contemporary constructions of what it meant to be a woman. ${ }^{5}$

\section{Act 1-England and the Isle of Wight; Enter the Actress}

The stage, in various forms, was a constant through Lotti Wilmot's career. Light theatre was her first entrée into stage life, and later in her career, it supplemented lecturing and spiritualist work. Like so many other entertainers in the nineteenth century, Lotti's acting career was varied. Show life was busy and financially precarious, and few entertainers could afford to 
specialize, especially those who played at the popular and variety end of the market. ${ }^{6}$ During the 1860s, the teenaged Miss Lotti Wilmot appeared in minor London theatres and playhouses: in "miscellaneous entertainment" alongside conjurers, as part of a "singing burlesque" routine, in music halls, Christmas pantomimes, light comedy and farce. Such bit parts garnered little notice, although one reviewer did comment on her (as Lucy in That Rascal Jack) as a "fine specimen of the tall waiting-maid who is a good-looking and agreeable young person."7

By the early 1870s, Lotti had joined the company at London's Adelphi Theatre on The Strand. That venue, opened in 1806 as the Sans Pareil, specialized in melodrama, farce, comic operetta and dramatic adaptations of published works. The Adelphi's programme was broad, and alongside the acting cast, the theatre had a corps de ballet, singers, chorus dancers, composers, an orchestra, and a full front and back of house management team. ${ }^{8}$

Over two seasons, Lotti appeared in nine of the 39 productions staged at The Adelphi, playing minor roles in some of the theatre's longest-running and most popular pieces. She played Julia in all 82 performances of The Adventures of Fritz, Our Cousin-German, the hit of the 1872-1873 season; during the same season, she appeared in all 137 performances of the farce The White Hat. In common with other theatres at the time, The Adelphi ran different productions simultaneously, and actors frequently played two characters in separate productions on the same day. During the 1871-1872 season, Lotti appeared in Autumn Manoeuvres and The Irish Tutor, which ran at the same time; these two plays began the day after the Christmas pantomime's extended run finished, and they stopped two days before another major production started. ${ }^{9}$

Lotti left The Adelphi Theatre during the 1872-1873 season and played at various theatres before she joined the Holborn Theatre in 1874, playing Pauline in Edward BulwerLytton's popular melodrama The Lady of Lyons. There she appeared under the management of theatre director/lessee Fred Hughes, and then worked with him in London and Cambridge over the following year. In mid-1875 she and Hughes appear to have taken over The Globe in London, a theatre that had struggled since its opening six years earlier. It was a short-lived proprietorship, perhaps due to lukewarm reviews of their productions. Lotti's reprising of her role as Pauline flopped. According to one reviewer, "she has scarcely a requisite for the part; there is nothing graceful in her appearance, nor a vestige of ability in the performance." Within a few weeks, the Wilmot-Hughes partnership formed the London Comedy Company and took the Theatre Royal in Ryde on the Isle of Wight for the season.

Perhaps Lotti's work improved, or the Isle of Wight audiences were less discerning than those in the metropolis; she and the London Comedy Company were hits with their productions of The Bonnie Fishwife and The Love Chase. As the female lead in the latter, Lotti was said to be "all that could be desired, her acting being full of grace, and her elocution being A1"; she was, one reviewer noted, "simply perfect."

Even so, success was fleeting. Lotti claimed she was being maligned, as rumours spread that she could not meet her engagements at the Ryde Theatre. She offered a reward to anyone who could forward her copies of letters apparently circulating about her conduct in the Isle of Wight, and threatened legal action against the perpetrators. Some substance lay behind the allegations. The owners of the Ryde Theatre got into financial difficulties and seized Lotti's hired wardrobe, most likely as collateral, and there was talk of a "rather expensive lawsuit."12 It was a portent of things to come in the colonies, for which Lotti took ship in mid1876 , taking her young daughter Ada, her pet deerhound, and a case of champagne. ${ }^{13}$

\section{Act II-The Australian colonies; Enter the Inspirational Lecturess}

For many nineteenth-century migrants, the process of moving to a different country was a chance to get ahead and make a new life. It was more a chance for a make-over for Lotti 
Wilmot. She arrived in Australia with a new past, and quickly set about trying to forge a new acting career. Within 18 months of her arrival she had transformed herself into a social reform and temperance lecturer, and a defender of religious faith against iconoclastic priests and spiritualists.

Mrs Lotti Wilmot, widow and "Professional" arrived in Melbourne in October 1876. ${ }^{14}$ The champagne had come in handy on the voyage during which the other passengers were, Lotti believed, "unsympathetic" towards her. She passed her time on deck eating cake and drinking champagne, spurning the advances of the ship's captain, "a very red-nosed Scotchman." She quarrelled with one older gentleman, and when he refused to apologize, Lotti horsewhipped him publicly. ${ }^{15}$

In Australia, Lotti got down to business rapidly. Less than a fortnight after stepping ashore, this "late directress" of London's Globe and Holborn theatres, as she now grandly styled herself, made her first stage appearance - a series of readings, in character, from favourite comedies. ${ }^{16}$ She also appeared in the Fakir of Oolu's variety show of illusions, comedy and panorama, which included a send-up of spiritualists and mediums. Reviews were mixed (and Lotti regretted she did not horsewhip one of the critics), but she was re-engaged for another 12 performances. ${ }^{17}$

Lotti had brought with her from England the sole rights to perform a number of French dramas, and she hoped to produce and appear in these in Australia. When Brisbane theatre manager and West Indian tragedian Morton Tavares offered to stage the works, Lotti moved north to take up the offer. Tavares promoted her as a comedienne, but he was unimpressed with the quality of the works she brought with her, claiming he had no resources to stage them. Lotti reluctantly agreed to play Lady Macbeth opposite Tavares in a production of Macbeth, a role she had performed in one of her final appearances in England. ${ }^{18}$ The audience found her demeanour (and accent) unequal to the task, but hoped she would appear again in a more congenial part. ${ }^{19}$ Tavares's offer of the role of Gertrude in Hamlet on the following night was not at all congenial to Lotti, and she began legal action for breach of contract. ${ }^{20}$

The Brisbane School of Arts was more to Lotti's liking, and soon she was its "directress." She pulled together an eclectic show designed to appeal to all tastes. She gave dramatic recitals (including recently spurned Shakespearean roles), and there were musicians, jesters, and the Royal Tycoon Troupe of Japanese-contortionists, tumblers, illusionists, bamboo performers and other exotic entertainers. After a short run and a final benefit performance for Lotti, she moved to Sydney early in 1877 where she finally managed to have one of her dramas staged. ${ }^{21}$ Rag Fair was a "bad adaptation of a five-act $17^{\text {th }}$ century French melodrama," according to theatre historian Jill Dimond. ${ }^{22}$ The plot was complicated, the play long, and on the first night, the audience hissed the cast; it fizzled out after less than a week. ${ }^{23}$

This was not an illustrious start to a new career, but it set the pattern for things to come. Lotti's disagreement with Tavares proved to be the first of many she would have with theatre managers and other business people in her eight years in Australasia. This contretemps, like the others, would spiral into financial and social difficulties. Lotti had to pawn some of her jewellery to raise money for passage out of Brisbane. In Sydney she lived in a boarding house that turned out to be a sly-grog shop; she gradually sold off her valuables to support herself and her daughter, and eventually ran a refreshment booth at Blondin's tightrope performances. Bit parts in comic routines were not enough to live on, and around the middle of 1877, Lotti took over the proprietorship of a cigar counter. The "Nil Desperandum (Never Despair) Cigar Divan" was located in a bootmaker's shop in the heart of Sydney's theatre district, and it may have doubled as a front for prostitution. ${ }^{24}$

If popular theatre was a socially questionable career choice for young women, then running a tobacco store was to enter a murkier world beyond the margins of respectability. ${ }^{25}$ Lotti was harassed by "bloated young swells" and "old men rakes" who took goods on credit. 
Another resident in the street assaulted her and smashed her display cases (and she later sued him for damages). She fell behind with the rent, her stock and fixtures were seized; creditors and money lenders, reading a sexual code in her status, suggested she work the streets or offered to "give her a receipt in full on certain terms." 26

It was during this "perfect network of troubles" that Lotti claimed to discover her "mission"- to become a lecturer on temperance and social reform. ${ }^{27}$ By early 1878 , she was on stage again, but in a very different persona. As "Madame Lotti Wilmot," she donned pseudo-clerical garb - a plain black dress with white bands at the neck - and embarked on a career as a social reform lecturer. The taste for champagne was apparently eschewed, in public at least, for Lotti now claimed intemperance to be the greatest blot on civilization. Her name and costume may have been novel, but her remedies for social change were not: changes to the licensing laws, total abstinence and the avoidance of "bad company.",28

For the next two years, Lotti lectured, sometimes twice a week, on these topics in and around Melbourne, Sydney and Newcastle. Along with temperance, her special areas of interest included women's rights and social reform in general: women's education, the "Chinese Question" and marriage (too many bachelors in her opinion, and she provocatively suggested a tax on single men). More risqué topics spiced up her repertoire, including crime, contagious diseases, and the "Social Evil." To find suitable material for such talks, Lotti would visit hospitals, prisons and the red-light districts of major towns. This type of hands-on investigation of slums was beloved of contemporary social reformers, and Lotti joined a long line of commentators who mapped the dark underbelly and erotics of the Victorian city. ${ }^{29}$

Alongside these subjects, Lotti also spoke on spiritualism. The idea that the living could contact and communicate with the dead, especially through mediums, gained popularity in the United States and Britain from the 1850s. With their supposed greater level of passivity (and therefore openness to the spirit world), women were important as mediums. Between the 1860 s and 1880s, the "golden age" of spiritualism, women conducted private and public séances, wrote and lectured publicly on spiritualism. By the time Lotti turned her attention to this, there was a healthy if minority interest in spiritualism in Australia, and several noted spiritualists made speaking tours. ${ }^{30}$

Lotti, however, was an ardent opponent and naysayer of spiritualism rather than a supporter. The subtitle of one talk outlined her stance: "defending the Established Church against ALL COMERS. Church and Temperance v. Diseased Brains and Jugglers." Spiritualism was a "gross imposture," she argued, offering nothing to an intelligent mind. It encouraged immorality, and sought to destroy conjugal felicity and happiness. In her view, all mediums should be publicly tested, "without the absurd aid of chairs and tables" in order to prove they were truly inspired. ${ }^{31}$

Lotti threw herself into a public battle for faith. For some months she pitted herself on the lecture circuit against noted English spiritualist Emma Hardinge Britten, also a former actress from London's Adelphi Theatre. Lotti might talk on the evening following Emma's lecture, sometimes taking similar subjects or titles, but normally pointing out what was wrong with spiritualism. Violent protest had greeted Emma at some of her American lectures, and she had been threatened with a lynching; Lotti's talks - and challenge to meet in Sydney's Hyde Park to test the origins of Emma's inspiration - most likely had minor annoyance value for the experienced spiritualist and stage woman. She had bigger fish to fry. There were more outspoken and prominent opponents of her talks than Lotti Wilmot, and other spiritualist speakers were in Australia at the same time, attracting large audiences. Emma's attention was on ensuring the financial success of her own tour. ${ }^{32}$

Lotti continued her defence of religion when Canadian Pastor Charles Chiniquy arrived in Australia, ostensibly for a rest, but in reality, beginning a two-year, 610-lecture tour of Australasia. Chiniquy was an excommunicated Catholic priest turned Presbyterian who 
took his role as lapsed Catholic very seriously. His talks were strident attacks on the Catholic faith and the Catholic Church, and he had an eye for the sensational-trampling communion wafers, publicly denouncing the Pope. ${ }^{33}$

Along with some clergymen and local politicians, Lotti initially supported Chiniquy, believing that he would not get a fair chance to state his views. Her support faded fast, and within weeks of Chiniquy's arrival, Lotti launched a series of lectures that purported to tell the real reason why he left the Catholic Church. She hinted at sordid sexual affairs, and took issue with his treatment of female parishioners. ${ }^{34}$ She worked "heart and soul" in the Catholic cause, she claimed, believing that Catholics, "and especially the ladies," were being traduced by a renegade. Her talks drew appreciative crowds in Melbourne and Tasmania.

Feeling was running high against Chiniquy and in Hobart, rioters stormed his lectures. Lotti lectured there shortly afterwards, and in the view of one journalist on the Australian Town and Country Journal, the timing was far too coincidental. Lotti and the pastor were in cahoots, he argued; Chiniquy would stir up the locals, netting a "nice little sum" and Lotti would then appear the following week, abuse him "right and left, to the amusement of the audience" and then join Chiniquy to share the spoils. Lotti sued the paper for libel and, representing herself, won the case, receiving $£ 150$ of the $£ 5000$ she claimed in damages. ${ }^{35}$

Between the time of the allegations and when the case went to court the following year, Lotti shifted course again, commencing yet another performance for a different audience. She continued to speak on the same topics, but the tone hardened. She roundly castigated those she considered responsible for the parlous state of Australia's cities. Reviewers commented on the earthy and sometimes "immodest" nature of her talks, which now encompassed witty and vituperative attacks on the press and other detractors.

Financial and social difficulties reappeared. Lotti was sued for not paying for posters advertising her talks, and she accused the Post Office of withholding her mail and stealing money. She reprised her acting career, and "humorous sketches" made their way back into her repertoire. She advertised for the services of a good business manager-sorely needed as she was not always able to cover the costs of renting her venues. During the libel case against the Town and Country Journal, she argued that the accusation of being in league with Chiniquy harmed her professional reputation and her audience numbers had dropped in consequence. ${ }^{36}$

Her lectures also took on a decidedly anti-religious tone. By the middle of 1879 she was describing herself as unsectarian and a freethinker. She criticized the clergy and traditional churches in her public lectures. She was charged in court with lecturing on a Sunday - a favoured ploy of freethinkers - and later opened her own "reading-room" where she gave anti-clerical lectures. ${ }^{37}$

The libel case against the Australian Town and Country Journal was a pyrrhic victory for Lotti. She may have won-and celebrated her victory by announcing her candidature for Parliament representing Newcastle, despite women not having the vote-but the case dredged up stories of her bad old days in Australia; the failed acting career, the dubious time behind the cigar divan counter in Sydney, other court cases. A month after the verdict Lotti was declared insolvent. She was not in court that day; she had packed her bags, taken her daughter and pet spaniel (her "favourite hound" had recently died) and sailed for New Zealand.

\section{Act III-New Zealand; Enter Madame Lotti Wilmot, Freethinking Medium and Table- tilter}

The Lotti Wilmot who stepped ashore at Dunedin in September 1880 was a very different character from the one who had arrived in Melbourne four years earlier. It was not just a change in career that had seen her shift from actress to lecturer, nor a conversion experience that turned anti-spiritualism into freethinking spiritualism. She had fashioned a new identity for the new audiences that awaited her. 
At some point during her time in Australia Lotti told the story of her life before she travelled to the colonies. She was, she claimed, born in London in 1849 to French parents. Imbued with a passion for public life and independence, she went on the stage in 1864 . Three weeks later, she married a wealthy gentleman from Bombay and retired from public life. Impatient for adventure and of a restless disposition, she travelled the Continent and worked in hospitals during the Franco-Prussian war. Her husband died in 1874, and she was left to raise her daughter. She speculated in theatrical management and leased London theatres. Then, with a large company, she made a successful tour through the English provinces before sailing to Australia in 1877. Unscrupulous types had taken advantage of her, but she never shirked from exposing tyranny or the abuse of power. This uncompromising position gained her as many friends as enemies.

Here was a portrait of a woman with a strong sense of social justice and who was not afraid to make a stand for her principles. It was also a portrait frequently repeated, and periodically tweaked, during Lotti's time in New Zealand. She claimed she had travelled "almost entirely over the world [and] worked in military hospitals"; she had "seen life from every point of view." 38 This was no longer plain Mrs Lotti Wilmot, but Madame Lotti Wilmot, with everything such an exotic persona and experience suggested.

Lotti billed herself as an "inspirational lectureress" and "social progressionist," and the subjects of her New Zealand talks followed the pattern set in Australia. She continued her exposure of the dark side of city life. In Auckland in early 1881 she tried to gather the details of a rape trial by hiding, heavily veiled, behind a pillar in the courtroom after the judge had ordered the room cleared of all women and children; she claimed to be "taking notes for the newspapers." Private detectives were said to escort her around the most notorious bars, arrange her entrée into brothels, and provide introductions to prostitutes.

She used such information in her talks to illustrate what she saw as the hypocrisy of prominent members of society, and relished telling stories of those she saw scurrying through the back door of premises she visited. The titles and substance were often the same, or adapted for the local audience; "Melbourne By Day and By Night" became "Christchurch By Day and By Night."

The freethought ideas she adopted in her last few months in Australia featured strongly in her New Zealand programme. By the 1880s, New Zealand had a small but strong freethought movement, with formal associations in a number of centres. Freethinkers valorized logic and reason, and spoke against systems based on tradition or orthodoxy. They pitched themselves as modern and enlightened thinkers who had broken free of benighted religious faith, particularly organized Christianity. Local and international freethinkers toured New Zealand, attracting good crowds who enjoyed hearing passionate speakers deride clergy and the church. ${ }^{39}$

New Zealand's freethought community was fractured and fractious. Its adherents "found it difficult to agree on what they stood for," historian John Stenhouse notes, and Lotti entered the infighting with her customary verve. ${ }^{40}$ She quarrelled publicly with Dunedin freethinkers within days of arriving in New Zealand (they wanted to control her talks, she claimed), and she took issue with local freethought leaders whom she considered to be hypocrites. In court just two months after her arrival (claiming damages for breach of contract), Lotti represented herself, facing off against prominent freethinker Robert Stout, whom she mocked during the proceedings. ${ }^{41}$

Despite the frosty relationship with the freethought community, Lotti's talks followed their usual calls for social reform, combined with attacks on organized religion. She dissected Christianity - "built up by blood and carried on by terrorism," she argued. She gave witty and searing critiques of the Bible with its "impossible religion," comparing King Solomon to an old rooster in one talk. She blamed the Bible and Christianity for the inequality between the 
sexes, and demanded more reverence for women. The Genesis story, Adam and Eve, concepts of heaven and hell, sin, the Devil and angels, and the iniquities of clergy and institutional structures all came in for ridicule and rebuke. Christianity, in her view, impeded free inquiry and logical thought; it was in need of reform but spiritualism would be the way of the future. ${ }^{42}$

This was a far cry from the woman who just months before had defended the church against detractors and unbelief. Lotti threw herself wholeheartedly into her new role. Her attack on organized religion (and its adherents) was as strong as her earlier support had been. Freethinking speakers had a reputation for fiery and radical talks that entertained (and alienated) audiences. Lotti moved smoothly into this mode, and some audiences lapped it up; there were reports of wild cheers and applause, of "bands of disciples" who hung on her delivery and performance, which was generally agreed to be amusing, fluent and exciting.

The tone of her later Australian talks had already turned racy, and in New Zealand, they became much more explicit, perhaps as she appealed to the largely male and workingclass audience usually attracted to freethought events. ${ }^{43}$ Several reviewers commented on the "immodesty" of her lectures. These were "on the verge of being offensive to good taste," full of "coarse illusions," "absolutely beneath criticism" and not entirely suitable for the ears of respectable women. No doubt this was part of the attraction for some who attended: rough and tough talking from a women lecturer added a certain piquancy to an evening's entertainment, particularly a woman "who understands how effectively art may be induced to assist nature," as one reviewer noted appreciatively. ${ }^{44}$

Everyone had an opinion, but whatever its shade, it was all grist to the Lotti Wilmot mill. Her taste for public controversy and squabbles with the press that began towards the end of her time in Australia blossomed in New Zealand. Some papers-the New Zealand Herald among them-refused to send reporters to her talks. She courted publicity, on the stage, in letters to the editor, in street brawls such as that outside the Papanui Town Hall in 1881. She took umbrage, often noisily, with those whom she believed made her life difficulthotelkeepers who refused to allow her to keep her spaniel in her room, transport operators who inconvenienced her. Critics of her performances found themselves subject to counterattack from the stage or in the newspaper. She physically and publicly attacked the editor of Napier's Daily Telegraph following his review of her lecture "The Devil" ("valueless and very uninteresting," in his opinion), hitting him with a riding whip and exclaiming "that is for your insult." 45

All opponents, along with clergy and folk she considered as two-faced, were vilified in her publications relating her Australasian experiences. The only volume now extant, New Zealand Beds: A Sequel to Beds I Have Slept In, was a fast-paced travelogue "truthful and startling in its details" that related her triumphs and difficulties. "Our heroine," as she styled herself, spared her opponents nothing, and while she never named anyone, local readers would have known the subjects at the mercy of her pen. Describing herself as "fearless in the cause of public welfare," she warned that some "guilty consciences [might] shrink and shudder" at being painted in their true colours. New Zealand Beds, however, was more about publicizing Lotti's opinions about New Zealanders than about public welfare. Her 1880 visit to the Dunedin's slum area the "Devil's Half-acre" warranted half a sentence; her account of her contretemps with Mr Moon and the Papanui Town Hall Company received around half a chapter. $^{47}$

The once ardent anti-spiritualist did a full about-turn on the paranormal as well. Not content with just lecturing on spiritualism, Lotti became an embodiment of spiritualist belief. As a medium she channelled spirits, communed with the dead and ran public and private séances. ${ }^{48}$ Spiritualism had a small but committed following in New Zealand from the 1870 s. A number of local and international women mediums travelled the country over these years, lecturing on social reform and spiritualism to groups largely comprising the socially 
respectable. For a time, spiritualism's apparent scientific proof of human immortality appealed to freethinkers. It shared a similar impetus for social reform, and like freethought talks, those given by spiritualists were often public spectacles, particularly if the medium performed on stage.

Lotti took up her career as a medium early in 1881, although she had conducted a séance on her trip to New Zealand some months before. She held spiritualistic "classes," sometimes just for women, and private séances, sometimes just for men. Channelling spirits through "Joe," her "control" or link to the spirit world, and receiving messages through knocks or the tilting of a table were her favoured forms of communicating with the dead. Her spirits also caused furniture to move around the room. Unlike some mediums, she did not materialize spirits - that is, reproduce them in physical form-although her spirits were mobile and made physical contact with the sitters.

In these tasks, she was assisted by her teenaged daughter Ada-“a bright cheery little 'bit of jam"” as a reporter described her. Through "Joe," Lotti would commune with such luminaries as Voltaire-who appeared to have learnt English since he went to another world, one sitter quipped - and, more prosaically, the "late lamented Mr Wilmot." Perhaps some attended these séance in all seriousness, but the entertainment value of the events was high. "They are, without doubt, capital fun," a satisfied sitter declared. ${ }^{49}$

There may have been new opportunities for Lotti in New Zealand, but her financial and social difficulties took a turn for the worse here. Within weeks of arrival she appeared in court twice on the same day, once to answer charges of not paying for goods she ordered, and once as plaintiff alleging breach of contract against a theatre manager. She filed for bankruptcy, already over $£ 80$ in debt since her arrival, and her theatrical wardrobe was sold off. In these desperate times she turned again, as she had in Australia, to her acting roots. Her performance as Juliet in Romeo and Juliet was deemed an "absolute failure" with not a single redeeming trait. She lasted one night in the role, and the reviews of her terrible performance made it as far as British newspapers.

This was all a familiar story. The refrain of money owed, contracts breached and insolvency recurred at least two more times in the next three years. Bailiffs seized her goods and furniture in 1882, and testimony in the subsequent action Lotti brought to recover damages revealed that she had taken to carrying a pistol for her own safety. ${ }^{50}$

Early in 1884 newspapers reported that Lotti was ill, and had been for some months. She moved from Auckland to Upper Hutt where she died, in pain and in poverty. Her final months and death had their own controversy and sense of drama. It was said that Lotti was evicted from various hotels for not being able to pay her bills. This "castaway," as some described her, abandoned by her freethinking friends in her hour of need, was finally rescued by a Wesleyan minister who arranged her care in her final weeks. Apparently she cast off her spiritualist and freethinking ideas at the death and "presented her prayers to God through Jesus Christ as His Son." Freethinkers immediately argued over the circumstances of her death and the allegations made about their refusal to help a kindred spirit in her hour of need. Other faiths joined in what became a minor religious skirmish. ${ }^{51}$

\section{Epilogue: Staging a Life}

In his thesis on spiritualism in New Zealand, Shaun Broadley describes Lotti Wilmot as "fiercely independent, playfully controversial and cuttingly sarcastic, [who] wilfully transgressed social codes and the bounds of respectable womanhood both on and off stage." It is a perspective echoed by other historians. Dominic Alessio, who considers her spiritualist and social reform work in New Zealand, places her in a tradition of female radicalism. Her behaviour and beliefs helped shatter the common nineteenth-century stereotype of women, he argues; she was persecuted for her actions, "victimised as a kind of witch" for her ventures 
into the world of the paranormal. "Engaging, independent, witty and sarcastic" are among the terms Australian theatre historian Jill Dimond uses to describe Lotti. ${ }^{52}$

Lotti Wilmot pushed the boundaries of behaviour and lifestyle deemed appropriate for a nineteenth-century woman. Her initial career marked her out as a woman of a socially questionable status. The theatre may have been a popular leisure option in Victorian England, Australia and New Zealand, but it was not an entirely suitable profession for a woman. Social attitudes linked acting and prostitution-both worlds of make-believe, performance and sexual availablility. Acting of Lotti's usual type-light melodrama, farce, comedy and burlesque - appealed to the rowdy and popular "singing and dancing" audience, and was increasingly distinguished from the more tasteful and uplifting world of professional theatre. ${ }^{53}$

The social reform lecture circuit was a more respectable living, even though it was comparatively rare for women, particularly unaccompanied by a male partner, to be itinerant platform speakers. Lotti pushed those boundaries further still. Women lecturers tended to limit themselves to topics such as temperance or women's issues; they did not use their platforms to launch stinging critiques of clergy and local worthies; they did not make iconoclastic speeches attacking religious orthodoxy nor did they venture into the red-light districts of an evening for subject matter. Publications, if there were any, were impassioned pleas for women's rights or the end of the drink trade; they were rarely peppered with spleen and witty invective. Women mediums and spiritualists usually fitted the mould expected of them, both as women and as mediums: passive, and channelling motherhood as well as the spirit. Passivity was not in Lotti's nature. Temperament aside, she also belonged to the more dubious world of the peripatetic medium who performed in public, for money, and where charlatanism flourished. Unlike many public mediums, Lotti worked alone, with no male companion to protect her reputation, or her person. ${ }^{54}$

Off the formal stage of the theatre and speaking platform, Lotti was feisty and showy. She cut a distinctive figure with her large pet dogs at a time when society women preferred pretty lapdogs. ${ }^{55}$ Few women took matters into their own hands in the way she did-with pen, in court, or with the supplejack. She was not passive, submissive, or quiet. Yet there is much more to the Lotti Wilmot story than a stroppy woman defying convention and bucking gendered stereotypes, however attractive that might be to modern eyes. ${ }^{56}$ She challenged expected roles for women, but only to a certain degree. The stories she created about herself positioned her in a traditional gendered mould: wife, mother, widow, woman struggling against the world. Lotti's performance was both a confirmation of and challenge to contemporary notions of gender, and it serves to remind us of the shifting identities that any individual deploys. ${ }^{57}$

Lotti's performance also underlines the symbiotic relationship between performer and audience. Performance was, as Erving Goffman and other scholars remind us, inseparable from audience, and how the latter responded affected the nature of performance. ${ }^{58}$ The performer had to have an audience; the audience had no purpose without the player. Lotti's transgression of boundaries was part of the reason why she attracted audiences to her lectures. Her performance was not that of the usual female spiritualist or "lady lecturer." This straighttalking and provocative actress-lecturer-spiritualist was different: she was exotic and exciting, beautiful and tragic, she charted the unruly and indecent spaces in urban centres, and her behaviour hinted at a world of sexual adventure behind the explicit nature of her lecture topics.

Her staged body and sartorial style oozed a transgressive sexual allure. She was tall, and showed herself well. "Her commanding person ... was displayed to as much advantage as a dressmaker could make it," read a review of a lecture in New Plymouth: "In a black dress with bodice a la jersey [ie tight-fitting], black kid gloves extending over her wrists, and black sleeves exhibiting the naked contour of her arms, her figure was left untrammelled with 
excessive garb, and from a pocket over each breast was suspended a chain linked with charms. The conventional choker of the parson was worn round her neck." ${ }^{, 59}$ If newspaper reports of her talks and letters to editors were anything to go by, then New Zealand society had a scandalized fascination with her person and her conduct; morals were outraged and titillated in equal measure at her talks. Her much-vaunted skill with the cane on male flesh may have sent shudders of delight down some backs at this ultimate fantasy of female sexual dominance played out in public ${ }^{60}$ — and then replayed in newspapers and in court.

The highly charged stage of public sexuality was apparent in her talks on issues such as contagious diseases, prostitution and red-light districts, but it was also evident in Lotti's role as a spiritualist and medium. Women's spiritual and mediumistic powers may have relied on traditional ideas of female moral influence and passivity, but the performance of spiritualism was also an intensely sexualized moment, played out in front of an expectant audience. "Spiritualism was sexy," historian Marlene Troup has declared. It thrilled practitioners and detractors alike, and it often broke all bounds of accepted decency. In darkened rooms, attractive female mediums in trance-like states would bring forth spiritsperhaps young and female — who might caress and kiss male sitters. It was a kind of "sexual pandemonium" where mediums (and their spirits) would disrupt normal codes of conduct. ${ }^{61}$

Lotti's mediumistic events displayed the "awful liberation" of the séance table-for the medium and sitters alike. ${ }^{62}$ Along with daughter Ada, Lotti and her sitters might fly around the room, hands touching and "perspiring copiously" in an effort to keep with the madly gyrating tables moved by unseen spirits. Her spirits would touch the legs of male and female sitters. Lotti's control "Joe" might show "marked affection" for her and tip the table in her lap, or tell saucy jokes. None of this matched the sometimes outrageous and explicit behaviour of other female mediums, but it certainly created an evening of breathless entertainment and excitement, and the sitters lapped it up.

Auckland weekly newspaper the Observer captured the liminal public space Lotti inhabited: "The name of Lotti Wilmot naturally suggests to the experienced theatre-goer a mass of 'nicey-naughtiness' in tights singing 'I'm lardy-dardy swell,' and dancing the cancan." The "real Lotti" was "not that sort of girl at all." "63 Flouting convention only went so far, and in some respects, Lotti's narrative and performance reinscribed expected gender roles. Being respectable was important, and Lotti made an effort to portray her experiences in a positive light, justifying her work in the Sydney cigar store and distancing herself from what may have transpired there. Her anecdotes may have been "naughty," and she may have given men advice on courting women (and counselled women not to make themselves cheap), ${ }^{64}$ but her life story, as she told it, was the tale of a good and virtuous woman motivated by a strong sense of public service.

Her version of events - born of French parents, working as an actress in London for just a few weeks in 1864 before she met her wealthy husband from Bombay, charitable nursing during the Franco-Prussian war, being left a widow, managing successful theatre companies - was questionable. Lotti was not entirely the woman she presented herself to be. She was born in London in 1847 and was on the stage by 1862, before her fifteenth birthday. There she seems to have remained for the next 12 or so years, playing to mixed reviews in music halls, theatres, comedy companies and burlesque. She may have travelled to the Continent for a short spell of nursing during the Franco-Prussian War (1870-1871), but her stage appearances are reasonably well recorded over that time and she was living in London for the 1871 census.

Perhaps there was a gentleman from Bombay, but whether or not he swept Lotti off her feet and married her is a moot point. By 1864- the date Lotti claimed her three-week acting career ended for love and marriage - she had been on the stage as Miss Lotti Wilmot for at least two years. Her daughter Ada was born in 1866 and Lotti was back on stage within 
a month of the birth. Ada's birth certificate lists James Wilmot as the father and gives Lotti's birth name as Wootton; Lotti's death certificate gives her birth name as Wotton, her husband's name as Frank James Wilmot, and records the marriage as having taken place when Lotti was 17. I have been unable to find any records of the marriage which Lotti said took place in 1864, or of James Wilmot's death, which she dated to 1874, the year in which Lotti worked in a number of theatres and entered into partnership with Fred Hughes. Lotti continued to perform as Miss Lotti Wilmot for her entire career in the United Kingdom, and a "publicity" photograph she had taken in 1872 described her as "Miss Lottie Wilmott." Maybe she preferred to be known as "Miss" on stage even though her entry in the 1871 census lists her as a widow; maybe the story of a husband was a fabrication, used to garner respect and a place in the world. ${ }^{65}$

The story Lotti told of her life was part invention and part gloss on what had occurred; hers was a shifting identity as she made her own history, adapting to the circumstances in which she found - and placed - herself. She never tried to hide the acting background, but she certainly minimized its extent and boosted its status. In Australia and New Zealand she continued to reinvent herself, and the career changes and ideological flip-flops-never explained or commented upon-were part of this process. So too were her publications, generally reliable in their detail although highly partisan in their interpretations. ${ }^{66}$

Lotti was not a woman buffeted from one setback to another, nor was she forced to assume different roles in order to make her way in the world. She made her own way, seizing opportunities as they arose, creating a biography to fit her path. Lotti had an eye to the main chance, and her reinventions can be seen in this context. Time and again, she stepped in to a role where she saw a gap, whether the anti-spiritualist scene in Australia or the mediumistic circuit in New Zealand. Each time, the story she told of her life grew to match the situation.

The reinventions often occurred after some crisis, most often financial in nature: the move to Australia following the mixed tour of the Isle of Wight; the shift to a lecturing career after the failure of theatre work in Brisbane and Sydney and a period of ill health; the sudden appearance of mediumistic abilities just a couple of months after being declared insolvent. Finance probably motivated the process and mode of reinvention as Lotti offered exoticism in a market that appreciated and hankered after difference; novelty was the watchword of popular entertainment at this time. ${ }^{67}$ Working for and with others in the theatre did not pay off, and perhaps the potential attraction of being an independent female lecturer on salaciously topical matters held the promise of easier money. It was not to be.

The entertainment business was financially precarious and the work hard, even for established artists; for women making a living in this space, things were tougher. For most of her time in Australasia, Lotti operated without any management. She organized her own venues and tours, arranged for reviewers to attend performances, commissioned posters and advertising bills, liaised with transport companies and arranged her own publicity. Creating her own publicity stunts offstage may not have been surprising when viewed in this context. She had to find suitable accommodation for herself, her daughter and her dog-and the latter did not always make this an easy process, for there are several stories of Lotti being refused entry to hotels and boarding houses with the dog in tow. Like all entertainers, Lotti relied on good weather to bring in an audience. Few people would happily venture out at night along muddy and badly lit streets, and attendance at several of her public talks was hampered by poor weather. Her lectures, given without notes, could continue for an hour or more, so she had to look after her voice.

Entertainment was an industry that required stamina as well as versatility, and on several occasions, Lotti's health broke down and she took a break from the stage and lectern. Maybe theatre managers and owners of venues took advantage of a sole woman, as Lotti suggested, but it seems just as likely that she was not an astute businesswoman. Frequently 
she broke the terms of agreements or bunked town before paying her bills, and she did not understand why tradespeople would not supply goods on credit in what was a period of economic uncertainty. Repeated insolvencies attest to the difficulties she experienced and created.

Lotti's sense of opportunism was matched by her desire for publicity and controversy. Whether pitting herself against other speakers such as Emma Hardinge Britten, fulminating against the New Zealand press, making a scene in the street or denouncing the Bible, Lotti's behaviour created a show. In common with some other nineteenth-century actresses, Lotti's actions may have been attempts to control the public representations of herself, and her pamphlet New Zealand Beds could be read in this way. ${ }^{68}$ But as Jill Dimond notes, theatre and the lecture circuit thrived on conflict and drama. ${ }^{69}$ Lotti eagerly grasped chances to ignite debate and garner an audience. Publicity was even better when it came for free. Performance on the street, in the courtroom and as letters to the editor cost her only time but offered the public a morsel of what they could expect when they paid to see her perform.

Lotti's reinventions and different roles neatly segued into each other. She easily transferred skills from one type of stage to another: there was a smooth transition from theatre to lecture platform to séance table, and Lotti was among a number of women who followed this path. Each stage was a forum that gave women a space to speak, and to speak out in ways not easily available elsewhere. The same skills were necessary and on display: the ability to play a role, to make illusion seem real, to entertain, to take command on stage, to create a scene, to channel sexuality. For a woman such as Lotti-of strong opinions, with acting ability and a high degree of self-assurance - it became a world of possibility.

Lotti took the starring role in the production of her own life: as the heroine in the discursive stage that was New Zealand Beds, in the theatre of the street and spiritualist circle, treading the boards. Hers was performance in lived form, and every public appearance was an opportunity to stage her life. Even her final months were part of the theatre of death so beloved of Victorian society with its morbid fascination with death and decay. Newspaper reports of her demise have a scripted quality, and her supposed final injunction to daughter Ada to avoid freethinkers could have come straight from the pages of a melodrama.

Lotti's nineteenth-century audience was right to question the depth of her convictions in whatever role she was playing, whether formally on the stage or not. She could tell a good story, so well, in fact, that one reviewer thought Lotti had mistaken her vocation and would have been a better Christy Minstrel. ${ }^{70}$ Lotti was a show-woman, another pronounced, "going about from town to town to earn a precarious existence, and therefore it is hard to say and doubtful for us to believe whether she has any convictions." ${ }^{, 71}$

Yet that may not have mattered much at all to her audience, members of which were, of course, part of the game as well. For every person who came away offended from her performance, another chuckled broadly at the cheeky asides; for each person who cheered as she deconstructed Christian faith, another called her an infidel; her adherence to temperance was commonly known to be shaky at best. The sitters at her séances willingly and knowingly participated in her mediumistic charades. Despite the reporting of her activities on both sides of the Tasman, and the links in this "single market" of touring performers and news, no one questioned her reinventions, her seeming contradictions or volte-face on matters of faith. ${ }^{72}$ Lotti got away with it all.

Regardless of the nature of some of her topics, and the very real debates occurring over women's rights, freethought, spiritualism and matters of faith, Lotti's business was entertainment. Her audiences largely approached it in that spirit. I suggest that we should too, rather than dwelling too seriously on her as a figure of social reform, as a feisty pioneering advocate for women's rights, or trying to fathom the depths of her adherence to one philosophy or another. ${ }^{73}$ This is not to claim that Lotti's social reform stance was 
disingenuous, for she often took risks to research and express her views, even if those views changed like the wind. I do suggest, however, that her journey as a social reformer, antispiritualist and medium should be considered as part of a broader world of popular culture, and that she was a deliberate player in that world.

The strong market for lectures testifies to a lively interest in social reform and what historian John Stenhouse has termed "popular religion." 74 Yet as Caroline Daley has pointed out, New Zealanders liked their recreation to be rational as well as irrational-laughter and learning, desire and duty. ${ }^{75}$ Lotti offered an amusing night out, a bit of fun and games, a chance to participate in some social debate, and an opportunity to be nicely affronted if so desired. People could think on her message if they so wished, or spend a pleasant night at the theatre; they could even do both at the same time. Audiences could titter with vicarious pleasure as she lambasted social hypocrites of various persuasion. It was all very knowing. People could look and laugh, and in the séance room when the gas was turned down low, perhaps they could even touch.

Lotti's performances, in one form or another, continued after her death. She assumed the lead role in what turned out to be an ideological stoush between Wesleyans and freethinkers. That was eventually turned into a piece of bad verse- "Freethought weighed in the balance and found wanting"-and published in Australian papers:

List! List Freethinker, to a tale

New Zealand tells - 'twould turn thee pale

Did honest manhood aught avail,

And thou could'st heed:

Poor Wilmot found Freethought to fail

In her greatest need.

In want and sickness she appealed

To her dear friends - her hope, her shield;

And they respond and seek to gild

Her dying hour?

Ah no! Freethoughts were all congealed,

They lacked the power. ${ }^{76}$

Even more ignominiously, the mare "Lottie Wilmot" ran in the Tokomairiro races in 1885. Initially pipped at the post in the Farmers' Race, she eventually took first place after a protest lodged against the original winner, "Bruce."77

Appropriately enough, Lotti's life has been the subject of a drama, played to another audience. Sara Wiseman took the role of Lotti Wilmot in Stephanie Johnson's work "Strange Children" in 2005. In this story set in two time zones, nineteenth-century Lotti is a medium who helps grieving women contact their dead children; twenty-first-century Lotti assists a childless couple by becoming a surrogate. ${ }^{78}$ It is yet another staging of Lotti Wilmot before an audience, and like the roles she performed herself, one more reinvention.

\footnotetext{
${ }^{1}$ This sobriquet is part of the long description on the title page of Lotti Wilmot, New Zealand Beds: A Sequel to Beds I Have Slept In (Christchurch: Madame Lotti Wilmot, 1882). Material in this and the following six paragraphs is drawn from this publication, and also Star, November 21, 1880 and December 11, 1880, Press, November 18 and 22, 1881 and December 14, 1881, Liberty, November 19, 1881, quoted in Wilmot, New Zealand Beds, 50. Thanks to Peter Lineham and John Stenhouse for references and discussions about Lotti; I also appreciated the feedback and suggestions from the audience at the "Commanding An Audience" colloquium, University of Otago, November 2012, where I presented an earlier version of this paper.

2 Peter J. Lineham, "Christian Reaction to Freethought and Rationalism in New Zealand," Journal of Religious History 15, no. 2 (1988), 236-50, discusses such freethought habits.
} 
${ }^{3}$ Local studies of entertainment have rarely considered the role of individual players, focusing instead on the beginnings of theatre or particular theatres. Our studies of popular culture and entertainment are relatively thin, but growing. Caroline Daley's corpus of work is notable here, especially her most recent book, Leisure and Pleasure: Reshaping and Revealing the New Zealand body 1900-1960 (Auckland: Auckland University Press, 2003).

${ }^{4}$ See James Belich's concluding comments in Making Peoples: A History of the New Zealanders from Polynesian Settlement to the End of the Nineteenth Century (Auckland: Allen Lane and Penguin, 1996); see also Daley's Leisure and Pleasure as well as "Modernity, Consumption and Leisure," in The New Oxford History of New Zealand, ed. Giselle Byrnes (Melbourne: Oxford University Press, 2009), 423-45.

${ }^{5}$ A useful literature review of performance and gender is in Penny Summerfield, "Concluding Thoughts:

Performance, the Self, and Women's History," Women's History Review 22, no. 2 (2013), 345-52. I appreciate this reference, and helpful comments, from the reader of this article in draft form.

${ }^{6}$ For more on this, including in the New Zealand context, see Adrienne Simpson, Opera's Farthest Shore: A History of Professional Opera in New Zealand (Auckland: Reed, 1996), 14-15ff.

${ }^{7}$ Era, September 22, 1867; see also Era, May 18, 1862, February 28, 1864, December 30, 1866, March 3, 1867.

${ }^{8}$ Philip Allingham, "Theatres in Victorian London," accessed March 5, 2013, www.victorianweb.org/mt/theaters/pva234.html. For more on the Adelphi Theatre, see "The Adelphi Calendar Project," accessed March 6, 2013, www.emich.edu/english/adelphi_calendar. This site provides full cast lists for every year as well as summaries of the plays and commentary on the season. The theatre still operates from its address on The Strand in London. Front of house is now decked out in art deco style, but its repertoire of light musicals still hints at its nineteenth-century origins.

${ }^{9}$ Information on the season, cast and production at The Adelphi from "The Adelphi Calendar Project," ibid.

${ }^{10}$ Reynolds's Newspaper, July 18, 1875; see also the critical review of her performance as "Lady Gay Spanker" in London Assurance at The Globe, Era, July 18, 1875.

${ }^{11}$ Ryde News, September 14, 1875, quoted in Era, September 19, 1875; also Era, August 15, 1875.

${ }^{12}$ Era, September 10, 1875; Hampshire Telegraph and Sussex Chronicle, February 2, 1876.

${ }^{13}$ Review of Beds I Have Slept In, Observer, April 29, 1882.

${ }^{14}$ Parts of the Australian information in this section come from Jill Dimond, "Lotti Wilmot's Australian Beds," On Stage 12, nos. 2-3 (2011), 5-12.

${ }^{15}$ Review of Beds I Have Slept In, Observer, April 29, 1882.

${ }^{16}$ Argus, October 25, 1876; review of Beds I Have Slept In, Observer, April 29, 1882.

${ }^{17}$ Dimond discusses the show in more detail in "Australian Beds," 7.

${ }^{18}$ Era, November 28, 1875. In the London Comedy Company's performance in Gravesend, Macbeth and Hamlet were both on the bill. Tavares was a notable Shakespearean actor and played in New Zealand in the early 1870s following his London debut in 1869: Press, February 13, 1872. He opened the Queensland Theatre in Brisbane in 1874, employed his own company and was considered an important figure in bringing high-brow entertainment to the city: Errol Hill, The Jamaican Stage, 1655-1900 (Amherst: University of Massachusetts Press, 1992), 143ff.

${ }^{19}$ Brisbane Courier, November 15, 1876.

${ }^{20}$ The action appears to have gone no further. Lotti told her version of events in a letter to the editor, Brisbane Courier, November 25, 1876, and in more racy style in Beds I Have Slept In.

${ }^{21}$ Brisbane Courier, November 6, 1876, November 28, 1876. It was common practice for a company to stage a benefit performance on the final night of a series, with the profits going to the main performer.

${ }^{22}$ Dimond, "Australian Beds," 8.

${ }^{23}$ Brisbane Courier, February 20, 1877; Sydney Morning Herald, February 17, 1877.

${ }^{24}$ This shop ran advertisements for domestic servants, and men could leave their correspondence there to be addressed and readdressed. Lotti later hinted that this service was vaguely sexual in nature, although it was not clear what her role was.

${ }^{25}$ For more on the association of actresses and prostitution at this time, see Kirsten Pullen, Actresses and Whores: On Stage and In Society (Cambridge: Cambridge University Press, 2005). For more on the operation of tobacconists and "cigar girls," see Amy Gilman Srebnick, The Mysterious Death of Mary Rogers: Sex and Culture in Nineteenth-Century New York (New York: Oxford University Press, 1995), 51ff.

${ }^{26}$ Review of Beds I Have Slept In, Observer, April 29, 1882; Sydney Morning Herald, August 9, 1877.

${ }^{27}$ Review of Beds I Have Slept In, Observer, April 29, 1882.

${ }^{28}$ A Sydney newspaper suggested in 1878 that Lotti was inspired by whisky and "the beer tap": Sydney Once a Week, March 9, 1878, quoted in "Chasing Down Emma: Australia 1878: Spiritualism and Drunkenness," accessed June 12, 2012, ehbritten.blogspot.co.nz/2010/02/Australia-1878-spiritualism. One of her early talks on temperance is summarized in Sydney Morning Herald, February 18, 1878. 
${ }^{29}$ Many works discuss the Victorian urban investigator. Most useful for this paper were Seth Koven, Slumming: Sexual and Social Politics in Victorian London (Princeton: Princeton University Press, 2004); Lynda Nead, Victorian Babylon: People, Streets and Images in Nineteenth-Century London (New Haven: Yale University Press, 2000); and Judith Walkowitz, City of Dreadful Delight: Narratives of Sexual Danger in Late Victorian London (Chicago: Chicago University Press, 1992).

${ }^{30}$ The best study of nineteenth-century spiritualism is Alex Owen, The Darkened Room: Women, Power and Spiritualism in Late Victorian England (London: Virago, 1989); see also Janet Oppenheim, The Other World: Spiritualism and Psychic Research in England, 1850-1914 (Cambridge: Cambridge University Press, 1985). The Australian experience is well covered in Alfred Gabay, Messages from Beyond: Spiritualism and Spiritualists in Melbourne's Golden Age 1870-1890 (Melbourne: Melbourne University Press, 2001), and F. B. Smith, "Spiritualism in Victoria in the Nineteenth Century," Journal of Religious History 3 (1965), 246-60.

${ }^{31}$ Sydney Morning Herald, March 5 and 7, 1878.

${ }^{32}$ Sydney Once a Week, March 9, 1878, in "Chasing Down Emma: Australia 1878: Spiritualism and Drunkenness,” accessed June 12, 2012, ehbritten.blogspot.co.nz/2010/02/Australia-1878-spiritualism. The Hardinge Britten and Thomas Walker tours are discussed in Gabay, Messages from Beyond, 133-37. A major denunciation of spiritualism appeared in the Daily Telegraph on June 1, 1878 and Emma used her lecture in the Melbourne Opera House on June 9 to refute it. Her talk was published as Spiritualism: Is It a Savage

Superstition? (Melbourne: George Robertson, 1878); it does not appear to make any mention of Lotti Wilmot's challenges.

${ }^{33}$ Yves Roby, “Charles Chiniquy,” Dictionary of Canadian Biography Online, accessed October 11, 2007, www.biographi.ca.

${ }^{34}$ Lotti attended a public meeting in Melbourne to form a committee to ensure that Chiniquy had a good reception and the opportunity for freedom of speech; she offered the committee her rented hall as a meeting place: Argus, January 18, 1879.

${ }^{35}$ See Australian Town and Country Journal, August 16, 1879 and August 7, 1880 for accounts of the libel action in the Sydney Supreme Court.

${ }^{36}$ Australian Town and Country Journal, April 19, 1879 and August 7, 1880; Argus, September 15 and 25 , 1879; Sydney Morning Herald, September 17, 1880.

${ }^{37}$ Mercury, July 24, 1879; Launceston Examiner, July 15, 1879; Sydney Morning Herald, March $20,1880$.

${ }^{38}$ Hobart paper the Mercury, July 14, 1879, published a version, but there may have been others in Australia that predated this. It formed the substance of her own publications as well. See also New Zealand Herald, April 8,1881 .

${ }^{39}$ As well as Lineham, "Christian Reaction," good New Zealand studies of freethought include Jim Dakin, "New Zealand's Freethought Heritage. Chapter 3: the rise and decline of Freethought in Dunedin, 1880-90," New Zealand Rationalist and Humanist: A Journal on Philosophy, Science, Religion, Society 74, no. 2 (2001), 10-17; John Stenhouse, "Imperialism, Atheism and Race: Charles Southwell, old corruption, and the Maori," Journal of British Studies 44 (2005), 754-74.

40 John Stenhouse, "Religion and society," in The New Oxford History, ed. Byrnes, 335.

${ }^{41}$ Otago Daily Times, November 1, 1880; Evening Post, June 24, 1881.

${ }^{42}$ Taranaki Herald, June 27 and July 4 1881; Otago Daily Times, October 23, 1880; Daily Telegraph, February 21, 1881.

${ }^{43}$ Lineham, "Christian Reaction," discusses the freethought audience, 247; New Zealand Herald, April 7, 1881.

${ }^{44}$ Otago Daily Times, September 11 and 13, 1880, November 13, 1880; Daily Telegraph, February 21 and

March 7, 1881; Observer, April 2, 1881.

${ }^{45}$ Daily Telegraph, March 4, 1881; Observer, April 9, 1881.

46 There do not appear to be any extant copies of Beds I Have Slept In. Australian theatre historian Jill Dimond, who has published on Wilmot, called for copies of this work, to no avail: Dominion Post, February 6, 2010. The work was, however, reviewed extensively in the Observer in 1882 and its content may be discerned from those reviews.

${ }^{47}$ Wilmot, New Zealand Beds, passim.

${ }^{48}$ Her spiritualist work is discussed in Dominic Alessio, "Gender, Spiritualism and Reform in Late $19^{\text {th }}$ Century New Zealand: Lotti Wilmot's New Zealand Beds," British Review of New Zealand Studies 12 (1999/2000), 5586, and in Shaun Broadley, "Spirited Visions: A Study of Spirituality in New Zealand Settler Society, 1870-90" (PhD thesis, University of Otago, 2000).

${ }^{49}$ Accounts of some séances are in Daily Telegraph, February 18 and 22, 1881; Observer, April 2 and 9, 1881; Taranaki Herald, June 24, 1881. Oppenheim and Owen both discuss the processes of séances and the techniques of mediums. See also John Monroe, "Making the Séance 'Serious': Tables Tournantes and Second Empire Bourgeois Culture, 1853-1861,” History of Religions 38, no. 3 (1999), 219-46. 
${ }^{50}$ Otago Daily Times, October 23 and 27, 1880 and November 1, 6 and 18, 1880; Press, September 4 and 14, 1882.

${ }^{51}$ This account of Lotti's death was promulgated by Rev S. J. Garlick of Wellington, and reprinted in many papers; see Feilding Star, June 21, 1884, from which this version is drawn. For some weeks, main papers carried letters to the editor and articles from Wesleyans and freethinkers disputing the circumstances of Lotti's death and the extent of her freethought convictions. Freethought Review 10 (July 1884) and 11 (July and August 1884) carried several pieces on the matter.

${ }^{52}$ Broadley, "Spirited Visions," 160; Alessio, "Gender, Spiritualism and Reform," passim; Dimond, "Australian Beds," 5.

${ }^{53}$ Pullen, Actresses and Whores, 2, 109.

${ }^{54}$ See Owen, The Darkened Room, ch.3 for the best analysis on this topic.

${ }^{55}$ Dimond, "Australian Beds," 12, 3, 9 makes this useful point.

${ }^{56}$ Alessio, "Gender, Spiritualism and Reform," presents her as both hero and victim, suggesting she was persecuted for her beliefs. My reading of her life does not support a view of Lotti as victim, nor as someone whose primary motivation was one of public service.

${ }^{57}$ For more on the performance of gender and an individual's making of her or his own history, see the excellent literature summary in Penny Summerfield, "Concluding Thoughts," Women's History Review 22, no. 2 (2013), $345-52$.

${ }^{58}$ See Erving Goffman, The Presentation of the Self in Everyday Life (New York: Anchor Books, 1959), quoted in Katie Barclay and Sarah Richardson, "Introduction: Performing the Self: Women's Lives in Historical Perspective," Women's History Review 22, no. 2 (2013), 178; Summerfield's "Concluding Thoughts" also offers good points on the complex interplay between audience and performer and the effect each has on the other.

${ }^{59}$ Taranaki News, July 2, 1881, quoted in Wilmot, New Zealand Beds, 44. Broadley also discusses this aspect: "Sprited Visions," 160-61.

${ }^{60}$ Pullen discusses this with respect to nineteenth-century burlesque performer Lydia Thompson: Actresses and Whores, 127-28.

${ }^{61}$ Marlene Troup, "Spirited Sexuality: Sex, Marriage and Victorian Spiritualism," Victorian Literature and Culture 31, no. 1 (2003), 67ff. See also Owen, The Darkened Room, passim for more on this.

${ }^{62}$ Monroe, "Making the Séance 'Serious'," 228.

${ }^{63}$ Observer, April 2, 1881.

${ }^{64}$ For instance, in her talk on "Courtship and Marriage" in New Plymouth: Taranaki Herald, July 6, 1881.

${ }^{65}$ I have pieced together these details of her life through newspapers that carried notes of her perforrnances and theatre reviews. The earliest I found was an account of when Lotti, aged 15, performed in the Philharmonic Rooms in Oxford St: Era, May 18, 1862. A "Miss Wilmot" was also noted as performing in 1861 but it is not clear if this was Lotti. Like Dominic Alessio, "Gender, Spiritualism and Reform," I have not found her birth certificate or any record of a marriage certificate. Ada's birth certificate lists James Wilmot as the father, and Lotti's birth name as Wootton. I have not found official records for those names. Lotti is listed in the 1871 census as living in Wilton St, Westminster, a reasonably well-to-do area, with Mary Ann Wilmot. Her death certificate most probably contains errors: it gives her mother a different name (Mary Wolton), and identifies Lotti's husband as Frank Wilmot.

${ }^{66}$ New Zealand Beds contains long verbatim quotes from newspapers. Alessio verified a number of these in "Gender, Spiritualism and Reform," and those that I checked also matched the original.

${ }^{67}$ Simpson, Opera's Farthest Shore, 14.

${ }^{68}$ Pullen explores how burlesque artists sought to control their discursive representations: Actresses and Whores, $97 \mathrm{ff}$.

${ }^{69}$ Dimond, "Australian Beds," 10.

${ }^{70}$ Otago Daily Times, September 13, 1880.

${ }^{71}$ South Australian Register, March 28, 1881.

${ }^{72}$ The phrase is Caroline Daley's, from "Modernity, Consumption and Leisure," in The New Oxford History, ed. Byrnes, 435.

${ }^{73}$ In particular, see Alessio, "Gender, Spiritualism and Reform," passim; and Stevan Eldred-Grigg, Pleasures of the Flesh: Sex and Drugs in Colonial New Zealand 1840-1915 (Wellington: A.H. and A.W. Reed, 1984), 38$40,83,89$.

${ }^{74}$ John Stenhouse, "God, the Devil and Gender," in Sites of Gender: Women, Men and Modernity in Southern Dunedin, 1890-1939, eds. Barbara Brookes, Annabel Cooper and Robin Law (Auckland: Auckland University Press, 2003), 317.

${ }^{75}$ She explores this in "Modernity," in The New Oxford History, ed. Byrnes, 423-45, and also Leisure and Pleasure.

${ }^{76}$ Launceston Examiner, May 9, 1885, supplement. 
${ }_{77}^{77}$ Bruce Herald, April 24, 1885.

78 "Sybil Union," New Zealand Listener, June 25, 2005, accessed October 11, 2012, www.listener.co.nz; "Playwright uses campaigner as fertile medium," New Zealand Herald, n.d., 2005, accessed June 11, 2012, www.nzherald.co.nz. 